\title{
PERKEMBANGAN MONETER, PERBANKAN \\ DAN SISTEM PEMBAYARAN \\ TRIWULAN I - 2004
}

Tim Penulis Laporan Triwulanan I - 2004, Bank Indonesia

Membaiknya perekonomian dunia yang ditunjukkan oleh kinerja perdagangan yang terus meningkat, angka inflasi global yang masih relatif rendah, suku bunga internasional yang relatif stabil serta depresiasi dolar AS, mendukung kinerja perekonomian Indonesia pada triwulan I-2004. Pada periode laporan, proses pemulihan ekonomi Indonesia masih terus berlangsung ke arah yang diharapkan. Pertumbuhan ekonomi Indonesia mengalami kenaikan sesuai dengan perkiraan dengan didukung oleh stabilitas kondisi moneter dan keuangan yang kondusif, yang antara lain ditunjukkan dari nilai tukar rupiah yang relatif stabil, laju inflasi yang rendah, serta uang primer yang masih berada di bawah batas indikatifnya.

Pertumbuhan ekonomi Indonesia di triwulan 1-2004 diperkirakan tumbuh moderat hingga mencapai 4,3\% (yoy) dengan konsumsi sebagai penggerak utama. Sejalan dengan perbaikan ekonomi dunia, kegiatan ekspor dan investasi dalam triwulan laporan menunjukkan peningkatan. Secara sektoral, pertumbuhan positif terjadi di hampir seluruh sektor dengan sumbangan terbesar terutama berasal dari sektor pengangkutan dan komunikasi serta sektor listrik.

Laju inflasi dalam triwulan I-2004 tercatat sebesar 0,91\% (qtq) lebih rendah dari triwulan sebelumnya menandakan kecenderungan penurunan laju inflasi. Secara tahunan laju inflasi pada akhir triwulan I-2004 tercatat sebesar 5,11\% (yoy). Penurunan laju inflasi dalam triwulan laporan terutama didorong oleh melimpahnya pasokan baik karena panen raya maupun impor, rendahnya dampak harga-harga yang ditetapkan pemerintah (administered prices) dan relatif stabilnya nilai tukar rupiah yang secara rata-rata berada pada kisaran Rp8.3008.500 per dolar AS. Stabilitas nilai tukar rupiah ini terutama didorong oleh kondisi fundamental ekonomi domestik yang kondusif, ekspektasi pasar yang positif terhadap pergerakan nilai tukar rupiah, meningkatnya kepercayaan investor yang meningkat serta stabilitas sosial politik yang tetap terpelihara. 
Kecenderungan penurunan laju inflasi dan kestabilan nilai tukar tersebut telah memberikan ruang bagi penurunan suku bunga instrumen moneter secara hati-hati. Dalam triwulan I-2004, rata-rata suku bunga SBI 1 bulan dan 3 bulan masing-masing tercatat 7,42\% dan 7,33\%, atau turun masing-masing sebesar 89 bps dan 101 bps. Namun demikian, penurunan suku bunga SBI tersebut belum sepenuhnya dapat ditransmisikan kepada suku bunga kredit. Kondisi ini mendorong berkembangnya alternatif pembiayaan di luar perbankan antara lain melalui pasar modal dan obligasi.

Sejalan dengan kondisi moneter yang stabil, stabilitas sistem keuangan pada triwulan I-2004 berada dalam kondisi cukup terpelihara. Kinerja industri perbankan sampai dengan bulan Februari membaik, tercermin dari peningkatan jumlah kredit yang disalurkan. Sebagian besar kredit yang disalurkan tersebut untuk UKM. Meskipun kredit yang disalurkan mengalami peningkatan, penempatan dana perbankan di SBI masih tetap tinggi, terkait dengan tingginya ekses likuiditas dan persepsi bank terhadap risiko dunia usaha yang masih tinggi.

Dalam triwulan II-2004 mendatang, pertumbuhan ekonomi Indonesia diperkirakan akan berada pada kisaran 4,3-4,8\% (yoy) dengan konsumsi masih menjadi penyumbang terbesar, sementara peranan sektor investasi dan ekspor masih terbatas. Secara sektoral, sektor yang diperkirakan akan mengalami pertumbuhan tertinggi adalah sektor pengangkutan, bangunan dan listrik. Nilai tukar rupiah diperkirakan akan bergerak pada rata-rata Rp8.200-8.700 per dolar AS. Dari sisi domestik, perkiraan ini didukung oleh perkembangan fundamental ekonomi makro pada triwulan II-2004 yang diperkirakan tetap terpelihara baik sehingga diperkirakan akan menjadi penopang stabilitas nilai tukar rupiah ke depan. Dengan terjaganya pasokan bahan kebutuhan pokok dan nilai tukar rupiah yang stabil, inflasi ke depan diperkirakan masih dapat dikendalikan pada tingkat yang rendah. Inflasi IHK pada triwulan II-2004 diperkirakan sebesar 5-6\% (yoy). Untuk keseluruhan tahun 2004, inflasi masih sesuai dengan proyeksi semula yaitu 5,5\% (yoy) dengan deviasi $\pm 1 \%$.

Dalam triwulan mendatang, kebijakan moneter Bank Indonesia tetap diarahkan untuk mempertahankan stabilitas moneter dalam upaya mencapai sasaran inflasi jangka menengah dengan tetap memperkuat proses pemulihan ekonomi guna mendorong pertumbuhan ekonomi. Terkait dengan hal tersebut, ruang bagi penurunan suku bunga SBI masih terbuka namun harus dilakukan secara berhati-hati dan disesuaikan dengan upaya pencapaian sasaran inflasi. Sementara itu, untuk mengurangi fluktuasi nilai tukar yang berlebihan, intervensi valas akan dilakukan sesuai kebutuhan. Di bidang perbankan, Bank Indonesia akan terus melakukan langkah-langkah untuk terus memperkokoh kondisi perbankan nasional dan mendorong bank untuk meningkatkan fungsi intermediasinya. 
Secara keseluruhan, laporan triwulan I-2004 ini mencakup evaluasi pelaksanaan tugas dan wewenang Bank Indonesia di bidang moneter, perbankan, dan sistem pembayaran dengan penekanan pada evaluasi pencapaian sasaran inflasi dan sasaran moneter lainnya. Sistematika penyajian laporan terbagi dalam beberapa bab. Bab 2 memaparkan evaluasi Bank Indonesia atas perkembangan kinerja makroekonomi dan kinerja inflasi. Selanjutnya bab 3, 4, 5 masing-masing memaparkan evaluasi atas kebijakan dan perkembangan di bidang moneter, perbankan, dan sistem pembayaran. Bab 6 mengemukakan pandangan Bank Indonesia mengenai prospek ekonomi dan arah kebijakan mendatang termasuk permasalahan yang dihadapi perekonomian dan berbagai langkah yang akan ditempuh Bank Indonesia untuk mengatasinya. Dalam lampiran laporan ini juga disampaikan evaluasi kebijakan di bidang manajemen intern serta produk-produk hukum Bank Indonesia selama triwulan laporan.

\section{Evaluasi Perkembangan Makroekonomi dan Inflasi}

\subsection{Kinerja Makroekonomi}

Dalam triwulan I-2004 perekonomian dunia membaik, yang ditandai dengan peningkatan kinerja perdagangan internasional yang didukung oleh peningkatan permintaan agregat. Membaiknya perekonomian dunia tersebut telah membawa dampak positif bagi sektor eksternal. Kinerja neraca transaksi berjalan dalam triwulan I-2004 mengalami surplus sebesar USD1,4 miliar, lebih tinggi dibandingkan dengan surplus yang terjadi pada triwulan yang sama tahun sebelumnya.

Secara keseluruhan kegiatan ekonomi pada triwulan I-2004 diperkirakan meningkat sebesar 4,3\% (yoy), didukung oleh kegiatan konsumsi sebagai penggerak utama perekonomian. Total konsumsi diprakirakan tumbuh sebesar 4,60\% (yoy), tumbuh lebih tinggi dibandingkan dengan triwulan yang sama tahun sebelumnya. Peningkatan konsumsi tersebut terutama berasal dari konsumsi swasta seiring dengan meningkatnya daya beli masyarakat dan sumber-sumber pembiayaan serta didukung pula oleh meningkatnya volume impor barang konsumsi khususnya impor makanan dan minuman rumah tangga serta bahan makanan dan bahan minuman. Sementara itu, operasi keuangan Pemerintah diprakirakan akan mendorong pertumbuhan konsumsi Pemerintah sebesar $7,54 \%$ (yoy) terutama disebabkan oleh kenaikan anggaran belanja pegawai Pemerintah Pusat dan pengeluaran rutin lainnya. Di sisi investasi, kegiatan investasi diprakirakan tumbuh positif secara terbatas yaitu sebesar $1 \%$ (yoy). Mulai positifnya pertumbuhan investasi tersebut didukung oleh meningkatnya pembiayaan baik dari sisi perbankan maupun pasar modal. 
Kinerja ekspor pada triwulan I-2004 diprakirakan mencatat pertumbuhan 5,5\%. Kinerja ini didukung oleh peningkatan ekspor non migas yang sampai dengan Februari 2004 mencatat peningkatan volume pertumbuhan yang cukup signifikan. Peningkatan ini terutama disumbangkan oleh komoditi tambang sedangkan kelompok barang pertanian mengalami penurunan. Sementara itu, impor diperkirakan hanya tumbuh $2 \%$, lebih rendah dibandingkan dengan triwulan yang sama tahun sebelumnya.

Secara sektoral, seluruh sektor ekonomi diperkirakan mengalami pertumbuhan positif sektor pengangkutan, sektor listrik dan sektor bangunan mencatat pertumbuhan tertinggi.

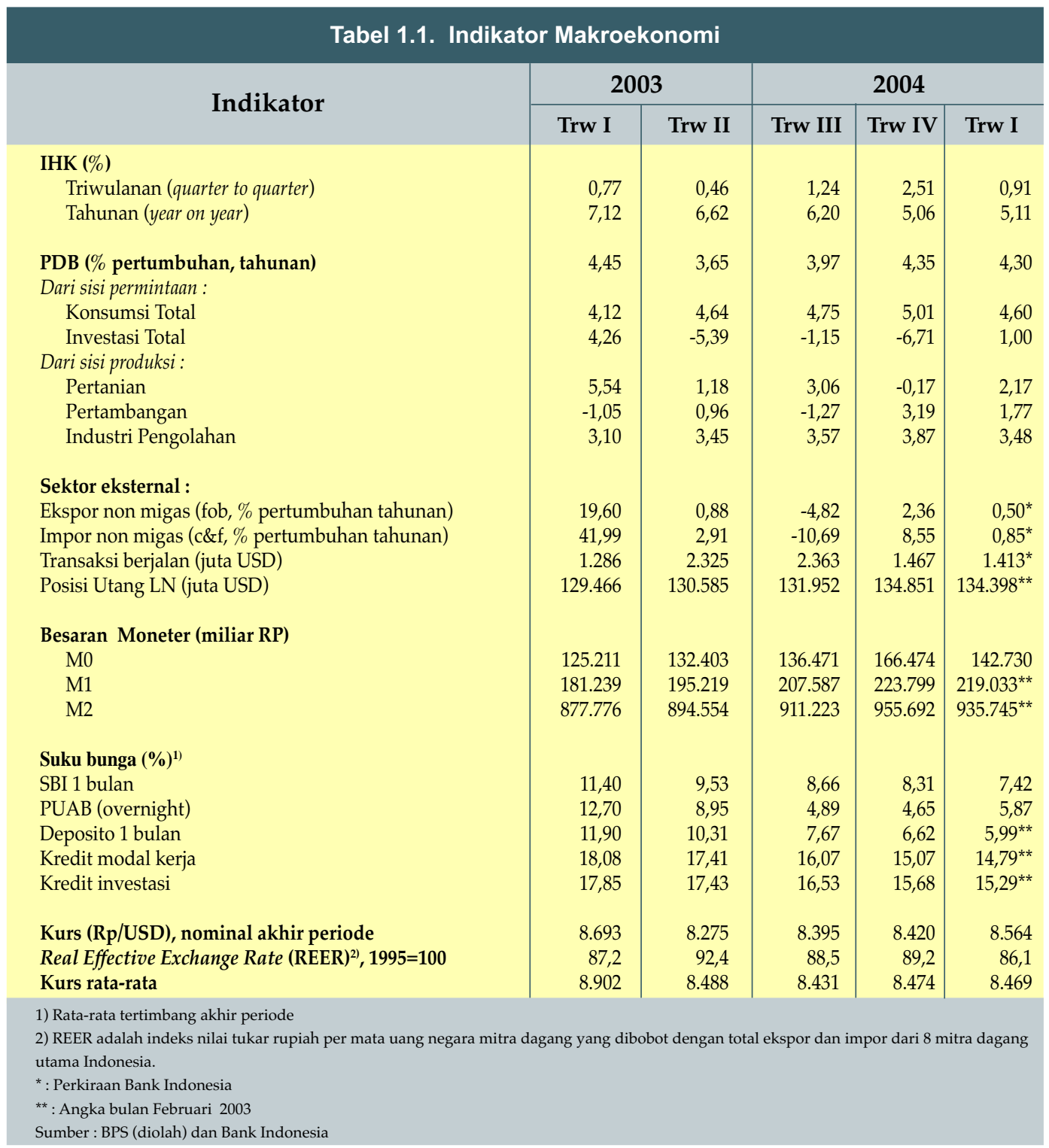


Pertumbuhan di sektor pengangkutan yang tinggi terutama didukung oleh kinerja subsektor angkutan udara, seiring dengan dibukanya beberapa tujuan penerbangan baru baik dalam maupun luar negeri serta harga tiket pesawat yang bersaing. Sektor bangunan diperkirakan tumbuh 6,94\%. Sejalan dengan pertumbuhan di sektor angkutan dan bangunan, sektor listrik juga diperkirakan akan mengalami pertumbuhan sebesar $6,91 \%$ terutama disebabkan oleh mulai beroperasinya beberapa pembangkit listrik di Sumatera dan Sulawesi.

\subsection{Kinerja Inflasi}

Laju inflasi selama triwulan I-2004 menunjukkan kecenderungan yang menurun seiring dengan perkembangan nilai tukar rupiah yang relatif stabil. Laju inflasi pada bulan Maret 2004 mencapai 0,36\% ( $\mathrm{mtm}$ ) sehingga inflasi IHK triwulan I-2004 mencapai 0,91\% (qtq) lebih rendah dari inflasi triwulan sebelumnya yang sebesar $2,51 \%$. Secara tahunan, inflasi IHK sedikit meningkat dari 5,06\% (yoy) pada triwulan IV-2003 menjadi 5,11\% (yoy) pada triwulan I-2004. Dengan perkembangan tersebut, realisasi inflasi IHK triwulan I-2004 berada pada batas bawah kisaran inflasi IHK 5-6\% (yoy) yang diproyeksikan pada awal triwulan.

Selama triwulan laporan, tekanan inflasi yang berasal dari sisi eksternal sangat rendah. Inflasi global termasuk inflasi negara-negara mitra dagang utama Indonesia yang menunjukkan menurun, ikut menyebabkan rendahnya tekanan inflasi yang berasal dari sisi eksternal. Selain itu, nilai tukar yang relatif stabil, mengurangi tekanan kepada tingkat inflasi. Disamping pengaruh langsung (direct pass through) pada harga barang-barang impor, kestabilan nilai tukar secara tidak langsung (indirect pass through) juga turut berpengaruh pada meningkatnya volume impor terutama impor non migas pada triwulan I-2004. Dari sisi internal, pasokan barang dari produksi dalam negeri yang melimpah, ekspektasi masyarakat yang membaik serta rendahnya dampak harga-harga yang ditetapkan pemerintah (administered prices) juga mendorong inflasi pada triwulan laporan relatif rendah.

\section{Evaluasi Perkembangan dan Kebijakan Moneter}

Secara umum, kondisi moneter pada triwulan I-2004 relatif stabil yang ditunjukkan oleh perkembangan besaran-besaran moneter yang stabil dan terkendali. Kestabilan ini didukung oleh masih kondusifnya faktor fundamental ekonomi domestik dan terjaganya ekspektasi inflasi. Perkembangan uang beredar masih terkendali di bawah target indikatifnya, suku bunga instrumen masih cenderung menurun serta perkembangan nilai tukar rupiah masih bergerak relatif stabil. 
Posisi uang primer pada akhir triwulan I-2004 mengalami penurunan sebesar Rp23,74 triliun dari triwulan sebelumnya menjadi Rp142,73 triliun. Penurunan tersebut terutama disebabkan oleh penurunan yang terjadi baik pada uang kartal akibat pola musimannya dan penurunan pada saldo giro. Sedangkan apabila dilihat dari faktorfaktor yang mempengaruhi, maka penurunan uang primer ini bersumber dari operasi pasar terbuka (OPT) perubahan posisi rekening pemerintah dan intervensi valas yang bersifat kontraktif.

Kecenderungan penurunan suku bunga SBI masih terus berlanjut sejalan dengan membaiknya ekspektasi inflasi, relatif stabilnya nilai tukar rupiah, dan terkendalinya uang primer. Dalam triwulan I-2004, suku bunga SBI 1 bulan turun 89 bps menjadi 7,42\% sedangkan SBI 3 bulan turun sebesar 101 bps hingga mencapai level 7,33\%. Penurunan suku bunga SBI ini lebih tinggi penurunan SBI pada triwulan sebelumnya yang masingmasing sebesar 35 bps dan 41 bps. Sementara itu, suku bunga FASBI menurun sebesar 75 bps sehingga mencapai $7,25 \%$ di akhir triwulan. Penurunan suku bunga instrumen moneter terutama FASBI serta masih melimpahnya likuiditas di pasar mendorong penurunan Rata-rata Tertimbang (RRT) suku bunga PUAB overnight rupiah hingga mencapai masingmasing 7,33\% untuk transaksi pagi hari dan 6,34\% untuk transaksi sore hari.

Trend penurunan suku bunga SBI diikuti pula oleh penurunan suku bunga dana khususnya deposito. Suku bunga deposito 1 bulan turun 63 bps sedangkan deposito 3 bulan turun 76 bps dari akhir triwulan sebelumnya sehingga masing-masing menjadi 5,99\% dan $6,98 \%$. Namun demikian, penurunan suku bunga SBI tersebut belum direspon secara proporsional oleh suku bunga kredit perbankan karena terkendala oleh pemenuhan target profitabilitas dan faktor risiko. Perbankan cenderung untuk mempertahankan spread suku bunga yang lebar karena belum efisiennya operasional perbankan, terutama karena masih tingginya biaya overhead dan upaya perbankan untuk mempertahankan laba sesuai target dalam business plan-nya. Suku bunga Kredit Modal kerja (KMK) pada triwulan I-2004 turun sebesar 28 bps dari posisi akhir triwulan sebelumnya menjadi 14,79\%, sedangkan suku bunga Kredit Investasi dan Kredit Konsumsi masing-masing turun 39 bps dan 22 bps sehingga menjadi masing-masing $15,29 \%$ dan $18,47 \%$.

Sementara itu, penurunan suku bunga instrumen moneter ini telah mendorong jalur transmisi moneter melalui pasar modal untuk pembiayaan sektor riil melalui penerbitan obligasi korporasi. Membaiknya kondisi makro ekonomi yang memicu aliran modal asing juga telah semakin mendorong peningkatan kinerja bursa saham pada triwulan I-2004. Kondisi tersebut tampak dari membaiknya IHSG, naiknya aktivitas pasar yang tercermin dari nilai perdagangan serta naiknya total net beli asing. 
Cukup kondusifnya faktor fundamental ekonomi domestik, ekspektasi pasar yang positif terhadap pergerakan nilai tukar rupiah, meningkatnya kepercayaan investor serta terpeliharanya stabilitas sosial politik mendukung nilai rupiah bergerak relatif stabil pada periode laporan. Meskipun sempat melemah pada paro kedua triwulan I-2004, rata-rata nilai tukar rupiah pada triwulan I-2004 relatif tidak berubah dibandingkan dengan triwulan IV-2003. Rata-rata nilai tukar pada triwulan I-2004 mencapai Rp8.469, sedikit turun dibandingkan rata-rata triwulan sebelumnya yang mencapai $R p$ 8.420. Relatif stabilnya nilai tukar rupiah tersebut antara lain terkait dengan faktor fundamental ekonomi domestik yang tetap kondusif, ekspektasi pasar yang positif terhadap pergerakan nilai tukar rupiah, meningkatnya kepercayaan investor berkaitan dengan peningkatan credit rating oleh lembaga peringkat internasional Moody's dan Fitch serta stabilitas sosial politik yang terpelihara.

Secara umum, pelaksanaan kebijakan moneter sepanjang triwulan I-2004 masih cukup tepat (appropriate) dalam mendukung kestabilan moneter dan kondusif bagi kelangsungan pertumbuhan ekonomi. Sejumlah indikator utama moneter seperti inflasi, nilai tukar dan suku bunga menunjukkan perkembangan yang relatif stabil dalam triwulan I-2004 dan sesuai dengan yang proyeksi semula. Perkembangan base money terkendali walaupun pada akhir periode cenderung mengalami penurunan yang cukup tajam mendekati pola normalnya. Sementara itu, suku bunga SBI 1 bulan mengalami penurunan.

\section{Evaluasi Perkembangan dan Kebijakan Perbankan}

Sejalan dengan kondisi moneter yang stabil, perkembangan beberapa indikator perbankan menunjukkan perbaikan. Fungsi intermediasi perbankan sedikit membaik sebagaimana tercermin dari peningkatan jumlah kredit yang disalurkan. Indikator-indikator perbankan lain seperti net interest income (NII), non performing loans (NPLs) serta rasio permodalan dan keuntungan bank, juga menunjukkan bahwa stabilitas sistem perbankan tetap terpelihara dan tidak terdapat indikasi adanya ancaman yang dapat mengganggu stabilitas sistem keuangan.

Sampai dengan triwulan I-2004 (Februari 2004), jumlah aset perbankan mencapai Rp1.157,2 triliun. Di sisi dana, total dana pihak ketiga (DPK) perbankan menurun Rp11,5 triliun dari triwulan sebelumnya menjadi Rp877,1 triliun yang antara lain dipengaruhi oleh meningkatnya kembali reksa dana serta penurunan dana milik BPPN sejalan dengan pembubaran lembaga tersebut. Sementara itu, posisi kredit pada triwulan I-2004 meningkat Rp0,1 triliun (0,02\%) menjadi Rp 477,30 triliun. Jumlah kredit baru selama triwulan I-2004 tercatat sebesar Rp4,3 triliun dimana sebesar 53,9\% disalurkan untuk sektor UKM. Menurut 
jenis penggunaannya, sebagian besar kredit baru disalurkan untuk kepentingan Kredit Modal Kerja sebesar 45,6\%, sementara sisanya untuk Kredit Investasi 24,3\% dan Kredit Konsumsi $30,1 \%$. Relatif kecilnya penyaluran kredit baru ini disebabkan oleh masih tingginya suku bunga kredit dan masih relatif rendahnya permintaan kredit yang tercermin dari peningkatan undisbursed loan. Kondisi ini mengakibatkan bank mengalami over likuid sehingga danadana tersebut ditempatkan pada SBI. Dengan perkembangan tersebut, loan to deposit ratio (LDR) perbankan nasional tercatat sebesar $42,9 \%$.

Membaiknya kinerja perbankan juga tercermin dari peningkatan NII dari Rp3,2 triliun pada triwulan IV-2003 menjadi sebesar Rp5,1 triliun pada triwulan I-2004. Peningkatan ini terutama disebabkan kecenderungan penurunan suku bunga dana pihak ketiga yang lebih cepat dibandingkan dengan penurunan suku bunga kredit. Sementara itu, Return on Asset (ROA) perbankan mencapai 2,6\%, meningkat dari posisi triwulan sebelumnya sebesar 2,5\%. Secara umum, permodalan perbankan pada triwulan I-2004 masih berada di atas kebutuhan minimum yaitu sebesar $23,2 \%$ meningkat dari triwulan sebelumnya yang sebesar $19,4 \%$.

Disisi NPL menunjukkan bahwa NPL gross perbankan meningkat dari $8,2 \%$ menjadi $8,3 \%$, sementara rasio NPL netto mengalami penurunan dari $3,0 \%$ menjadi $2,6 \%$. Rasio NPL tersebut berpotensi meningkat sebagai akibat dari memburuknya kondisi sektor tertentu seperti tekstil, baja, plastik dan kehutanan, serta telah jatuh temponya perlakuan kategori lancar terhadap kredit-kredit eks BPPN. Meskipun NPL meningkat, dalam jangka pendek peningkatan NPL ini tidak akan berdampak terhadap stabilitas sistem keuangan karena bank-bank telah membentuk PPAP dalam jumlah yang mencukupi.

Selama triwulan I-2004, kebijakan di bidang perbankan tetap difokuskan pada berbagai langkah untuk memperkokoh kondisi perbankan nasional terutama memperkokoh pemantapan ketahanan sistem perbankan antara lain melalui peningkatan good corporate governance perbankan dan penyempurnaan pengaturan dan pengawasan bank, serta untuk melanjutkan upaya pemulihan fungsi intermediasi perbankan.

Dalam kerangka penyempurnaan ketentuan perbankan, pada triwulan I-2004 Bank Indonesia telah mengeluarkan tiga ketentuan yakni : (i) Ketentuan tentang Tindak Lanjut Pengawasan dan Penetapan Status Bank yang merupakan penyesuaian ketentuan sebelumnya sehubungan dengan berakhirnya BPPN, (ii) Ketentuan tentang Penetapan Marjin Suku Bunga Simpanan Pihak Ketiga yang dijamin Pemerintah dalam rangka realignment suku bunga, (iii) Ketentuan tentang Pedoman Teknis Penilaian Kemampuan dan Kepatutan (Fit and Proper Test). 


\section{Evaluasi Perkembangan dan Kebijakan Sistem Pembayaran}

Di sisi pembayaran tunai, aktivitas pembayaran tunai dalam triwulan I-2004 sedikit mengalami penurunan seiring dengan menurunnya kebutuhan masyarakat terhadap uang tunai setelah berakhirnya hari-hari besar keagamaan dan tahun baru. Hal ini ditunjukkan dari menurunnya posisi Uang Yang Diedarkan (UYD) pada akhir triwulan I-2004 yang turun 9,29\% yaitu dari Rp112,75 triliun pada triwulan IV-2003 menjadi Rp102,27 triliun pada triwulan I-2004.

Total transaksi BI-RTGS pada triwulan I-2004 mencapai Rp6.729 triliun atau meningkat 7,95\% dibandingkan triwulan sebelumnya sebesar Rp6.233 triliun. Sementara itu, volume transaksi mencapai 1.123 ribu, atau turun sebesar $3,72 \%$ dari 1.166 ribu transaksi pada triwulan sebelumnya. Kondisi tersebut menyebabkan rata-rata harian nominal transaksi mencapai Rp112,1 triliun sementara rata-rata harian volume transaksi mencapai 18.726 transaksi. Ditinjau dari wilayah asal perintah transaksi RTGS, wilayah Jakarta memiliki pangsa volume dan pangsa nominal terbesar.

Di sisi lain, perkembangan aktifitas kliring selama triwulan I-2003 mengalami penurunan baik dari sisi nominal maupun jumlah lembar warkat yang diproses. Total nominal kliring penyerahan secara nasional mencapai Rp239 triliun dengan warkat sejumlah 14,7 juta lembar. Hal ini menunjukkan masing-masing penurunan nilai transaksi sebesar $20,8 \%$ dan volume transaksi sebesar $19,7 \%$ dibandingkan triwulan sebelumnya. Dengan demikian, rata-rata harian nominal dan volume turun masing-masing sebesar 3,9\% menjadi Rp4,9 triliun dan $26,5 \%$ menjadi 300 ribu warkat.

Secara umum, kebijakan yang ditempuh dalam sistem pembayaran tunai tetap diarahkan pada upaya pemenuhan kebutuhan uang rupiah di masyarakat dalam jumlah nominal yang cukup, jenis pecahan yang sesuai, tepat waktu dan dalam kondisi yang layak edar. Sementara kebijakan yang ditempuh dalam sistem pembayaran non tunai, diarahkan pada terciptanya sistem pembayaran yang efektif, efisien, aman, dan handal.

\section{Prospek Ekonomi dan Moneter serta Arah Kebijakan Ke Depan}

\subsection{Prospek Ekonomi Makro}

Kondisi perekonomian dunia yang terus membaik seiring dengan meningkatnya kegiatan ekonomi dan perdagangan internasional diperkirakan masih cukup kondusif dalam mendukung kinerja Neraca Pembayaran Indonesia (NPI), khususnya ekspor. Kinerja ekspor dan impor non migas diperkirakan meningkat dengan laju pertumbuhan masing-masing 
sebesar 3,7\% dan 9,9\% (yoy). Perkembangan ini memberikan dampak yang positif bagi pertumbuhan ekonomi Indonesia pada triwulan II-2004.

Prospek pertumbuhan ekonomi Indonesia pada triwulan II-2004 diperkirakan akan membaik dibandingkan dengan triwulan sebelumnya dan berada pada kisaran 4,3-4,8\% (yoy). Dari sisi permintaan, sumber utama pertumbuhan pada triwulan laporan masih berasal dari konsumsi yang diperkirakan tumbuh dalam kisaran 4,7-5,2\% (yoy). Di sisi fiskal, konsumsi Pemerintah diperkirakan masih akan tetap tinggi antara lain disebabkan meningkatnya pengeluaran yang terkait dengan kegiatan Pemilu.

Pertumbuhan investasi dan ekspor di triwulan II-2004 diprakirakan akan meningkat dibandingkan triwulan sebelumnya. Pengeluaran investasi yang masih tumbuh lemah pada awal tahun 2004 diperkirakan akan tumbuh lebih tinggi pada triwulan II-2004 dalam kisaran 2,4-2,9\% (yoy). Hal ini didukung oleh semakin bertambahnya sumber-sumber pembiayaan baik dari perbankan maupun pasar modal. Sementara itu ekspor barang dan jasa diprakirakan akan mengalami peningkatan sebesar 5,1-5,6\% yang terutama disumbang oleh membaiknya ekspor non migas dari negara-negara mitra dagang utama seperti Amerika Serikat, Jepang dan negara-negara kawasan Eropa serta peningkatan harga beberapa komoditi unggulan. Untuk keseluruhan tahun 2004, pertumbuhan ekonomi diperkirakan tetap seperti prakiraan semula yaitu pada kisaran 4-5\%. Secara sektoral, pertumbuhan tersebut terutama akan didukung oleh sektor pengangkutan, bangunan dan listrik meskipun penyumbang terbesar masih berasal dari sektor industri, pertanian dan perdagangan.

\subsection{Prospek Inflasi}

Pada triwulan II-2004, inflasi IHK diperkirakan masih rendah pada kisaran 5-6\% (yoy). Kecenderungan rendahnya proyeksi inflasi ini disebabkan oleh beberapa faktor fundamental seperti ekspektasi inflasi yang membaik yang didorong oleh terjaganya stabilitas politik dan keamanan dalam negeri, pasokan bahan pangan juga menunjukkan tingkat yang masih aman karena keberhasilan panen raya, dan relatif stabilnya nilai tukar. Di samping itu, kegiatan Pemilu diperkirakan telah mendorong ditundanya beberapa kenaikan administered prices terutama yang sangat strategis seperti BBM, listrik dan cukai rokok sehingga mengakibatkan tekanan inflasi yang berasal dari kebijakan harga Pemerintah cenderung lebih rendah. Untuk keseluruhan tahun 2004, inflasi IHK diperkirakan akan berada pada kisaran awal tahun yaitu $5,5 \% \pm 1 \%$ (yoy). 


\subsection{Prospek Moneter dan Nilai Tukar}

Sampai dengan akhir triwulan II-2004, uang primer diperkirakan masih akan meningkat seiring dengan masih cenderung turunnya suku bunga dan membaiknya prospek pertumbuhan ekonomi namun masih terkendali dalam kisaran proyeksi indikatifnya. Untuk sepanjang tahun 2004, proyeksi pertumbuhan uang primer diperkirakan masih akan tercapai seiring dengan proyeksi akan terus melambatnya pertumbuhan uang primer khususnya di kuartal terakhir 2004.

Dalam triwulan II-2004 nilai tukar diperkirakan masih akan bergerak stabil dengan rata-rata Rp8.200-8.700 per dolar AS. Perkiraan ini didukung oleh faktor-faktor antara lain stabilnya kondisi fundamental ekonomi domestik dan masih adanya kecenderungan melemahnya dolar AS sehubungan dengan besarnya twin deficit AS. Namun demikian, terdapat beberapa faktor risiko yang dapat memberikan tekanan terhadap rupiah. Kemungkinan berlanjutnya kebijakan intervensi pemerintah Jepang untuk menahan penguatan Yen terhadap dolar AS dikhawatirkan dapat mendorong pelemahan rupiah. Untuk keseluruhan tahun 2004, kisaran rata-rata nilai tukar rupiah tetap seperti prakiraan awal tahun yaitu Rp8.200-8700 per dolar AS.

\subsection{Arah Kebijakan Triwulan Mendatang}

Memperhatikan beberapa tantangan ekonomi dan prospek ekonomi-moneter ke depan, dalam triwulan mendatang arah kebijakan Bank Indonesia di bidang moneter, perbankan, dan sistem pembayaran sebagai berikut :

Di bidang moneter, kebijakan moneter tetap diarahkan pada upaya mempertahankan stabilitas moneter dalam upaya mencapai sasaran inflasi jangka menengah dengan tetap memperkuat proses pemulihan ekonomi dengan mendorong pertumbuhan ekonomi. Terkait dengan hal tersebut, suku bunga masih tetap dimungkinkan untuk turun secara berhati-hati serta konsisten dengan pencapaian target inflasi. Di sisi lain, untuk mencegah volatilitas nilai tukar yang berlebihan, intervensi di pasar valas akan dilakukan sesuai kebutuhan sejalan dengan pelaksanaan monitoring dan pengawasan transaksi devisa terhadap pelaku utama di pasar.

Di bidang perbankan, kebijakan diarahkan untuk melanjutkan upaya-upaya untuk mempertahankan stabilitas sistem keuangan dan perbankan serta mendorong peningkatan fungsi intermediasi perbankan. Disamping itu, Bank Indonesia akan meneruskan pelaksanaan sebagian dari 19 inisiatif Arsitektur Perbankan Indonesia (API), meliputi 
pembentukan panel ahli perbankan, mekanisme pengaduan nasabah, pendirian lembaga mediasi perbankan, transparansi informasi produk, edukasi konsumen, Good Corporate Governance, Credit Bureau, sertifikasi manajer risiko, linkage program dan pelonggaran ketentuan pembukaan kantor cabang BPR. Sementara itu, Menteri Keuangan dan Gubernur Bank Indonesia telah menandatangani Nota Kesepakatan Fasilitas Pembiayaan Darurat (FPD) yang merupakan bagian dari kerangka kerja Jaring Pengaman Sektor Keuangan. Dengan adanya Nota Kesepakatan tersebut, maka penanganan dan akuntabilitas dalam penyelesaian bank-bank yang mengalami kesulitan keuagan dan berdampak sistemik menjadi lebih jelas dan transparan. Namun demikian, pelaksanaan kesepakatan tersebut secara efektif masih memerlukan persetujuan DPR.

Di bidang sistem pembayaran tunai, kebijakan tetap diarahkan pada upaya untuk memenuhi uang kartal sesuai dengan kebutuhan masyarakat khususnya menyambut pelaksanaan Pemilu 2004 pada triwulan II dan triwulan III-2004. Di samping itu, Bank Indonesia juga terus meningkatkan koordinasi dengan pihak terkait dalam rangka memperlancar distribusi uang ke seluruh wilayah Indonesia, serta senantiasa melanjutkan upaya-upaya penanggulangan uang palsu antara lain melalui perluasan jejaring dan kerjasama dengan pihak-pihak terkait pada langkah penanggulangan uang palsu. Di sisi lain, dalam upaya mengenalkan masyarakat akan keaslian uang rupiah, Bank Indonesia akan menggunakan media elektronik dan media cetak sebagai sarana publikasi pengenalan ciri-ciri keaslian uang rupiah.

Di bidang sistem pembayaran non tunai, kebijakan tetap diarahkan pada upaya pengurangan risiko pembayaran dan peningkatan efisiensi serta pengaturan pelaksanaan sistem pembayaran guna mewujudkan sistem pembayaran nasional yang efisien, cepat, aman dan handal melalui pengembangan nota kredit paperless (PNK), penyusunan mekanisme failure to settle, pengembangan sistem kliring kredit paperless dan sistem kliring warkat debet serta penyusunan review blue print sistem pembayaran nasional. 